\title{
Dividend Changes and Future Profitability: Evidence from the Turkish Stock Market
}

\author{
Eyüp Kadığlu \& Nurcan Öcal ${ }^{1}$ \\ ${ }^{1}$ Capital Markets Board, Ankara, Turkey \\ Correspondence: Eyüp Kadığlu. E-mail: eyup.kadioglu@gmail.com
}

Received: January 16, 2016

Accepted: February 15, 2016

Online Published: February 25, 2016

doi:10.5539/ijef.v8n3p196

URL: http://dx.doi.org/10.5539/ijef.v8n3p196

\begin{abstract}
Most of the previous studies on dividends in Turkey have focused on the effects of dividend announcements. There has been no study investigating the relation between dividend changes and the future profitability of firms. This study investigates this relation by using both ordinary and panel data regression on a data set consisting of 1,239 dividend payouts from 123 companies listed in Borsa Istanbul during the period 2004-2014. This study is unable to demonstrate that dividend changes are related to changes in future earnings. No evidence is found to support the dividend signaling theory, which claims that dividends serve as indicators of the future profitability of firms. On the other hand, future profitability is found to be strongly correlated with profitability in the previous year.
\end{abstract}

Keywords: dividend changes, future profitability, information content of dividend, dividend signaling theory

\section{Introduction}

The question as to whether or not dividends or dividend changes convey information about future profitability has been the subject of studies for over 50 years. The dividend signaling theory has been proposed as an answer to this question. Although numerous empirical studies have tested this theory, the issue as to whether or not dividends or dividend changes contain information on the future profitability still needs clarification.

The information content of dividends was first proposed by Lintner (1956) and Miller and Modigliani (1961) and was formulized as the signaling theory by Bhattacharya (1979), John and Williams (1985), and Miller and Rock (1985). According to this theory, dividend changes contain information on future profitability.

Examples of studies that test the relation between dividends and future profitability include Watts (1973); Gonedes (1978); Penman (1984), Healy and Palepu (1988); Aharony and Dotan (1994), DeAngelo, DeAngelo and Skinner (1996); Bernartzi, Michaely and Thaler (1997); Nissim and Ziv (2001); Grullon, Michaely, Benartzi and Thaler (2005); Zhau and Ruland (2006); Hussainey (2009); Choi, Ju and Park (2011); Lee, Isa and Lim (2012); and Demontis (2013). While some of these studies conclude with results supporting the dividend signaling theory, some have reached contrary findings.

In Turkey, the following studies have reached conclusions regarding the information content of dividends by analyzing whether dividend announcements cause abnormal returns or changes in price: Aydoğan and Muradoğlu (1998); Muradoğlu and Aydoğan (2003); Batchelor and Orakcığlu (2003); Kadığlu (2008); Yılmaz and Selçuk (2010); Günalp, Kadıŏlu and Kılıç (2010); Gullajov (2014); and Kadığlu, Telçeken and Öcal (2015). On the other hand, the relation between dividends and future profitability has not been tested. Therefore, this study is the first to test the information content of dividends and the relation between dividends or dividend changes and future profitability in Turkey.

In order the test the relationship in question, this study utilizes the data of all companies distributing dividends in cash during the period 2004-2014. In this study, 1,239 dividend payouts of 123 companies listed in Borsa Istanbul are analyzed with regard to profit after tax, earnings per share and return on equity using ordinary and panel regression.

In conjunction with improvements in capital markets, previous studies on Turkish Stock Market found that the market gives reaction to dividend announcement, it is expected that changes in dividends will have likelihood of conveying information regarding the future profitability. 
The data concerning 1,239 dividends of 123 companies listed in Borsa Istanbul are analyzed using five different models introduced by Bernartzi, Michaely and Thaler (1997); improved by Nissim and Ziv (2001); and later used by Grullon, Michaely; Benartzi and Thaler (2005); Lukose and Rao (2010); Choi, Ju and Park (2011); and Lee, Isa and Lim (2012). No statistically significant relation is found between dividend changes and changes in earnings over the following two years. Therefore, it is concluded that dividend changes do not convey information on future profitability, and the dividend signaling theory is not supported. On the other hand, the future profitability or future earnings changes are found to correlate strongly with profitability in the previous year.

The second section of the study consists of a literature review, theories on the subject in question and the results of empirical studies conducted thus far. The third section presents the data set and method of empirical analysis used within the study. The fourth section discusses the results obtained. The final section summarizes the conclusions.

\section{Literature Review}

Information content of dividends was first suggested by Lintner (1956) and Miller and Modigliani (1961) and later formulized by Bhattacharya (1979), John and Williams (1985), and Miller and Rock (1985) as the signaling theory. The theory of signaling theory argues that dividend changes convey information regarding future profitability of the firms.

The phenomenon of information content of dividend started with Lintner (1956), who proposed that company managers believe that dividend changes correlate more strongly with permanent profit changes than with temporary ones. Furthermore, company managers possess a deeper-than-average knowledge of a company's future profitability and cash flows, and one of the most important factors that they consider when determining its dividend policy is the company's future profitability. On the other hand, managers prefer stable dividend payouts; therefore, they look unfavorably upon radical changes in dividend distribution. For this reason, current dividend ratios are changed gradually in order to reach a target dividend payout ratio.

Even though Miller and Modigliani (1961) argued that dividends do not change a company's capital structure or value in a system of perfect competition and no taxes, they accept that dividends can convey information because company managers acquire special knowledge concerning the future performance of a company. They claim that managers use dividends as a tool to signal a company's future profitability. According to Bhattacharya (1979), under imperfect market conditions, dividends are a costly signaling method used for removing asymmetrical information between company managers and shareholders regarding future cash flows of the company.

Although the information content of dividends has not been modeled perfectly, information content and the signaling theory have been tested in two ways: Firstly, the relation between dividends or dividend changes and future profitability or changes in earnings have been analyzed. Secondly, it has been investigated as to whether or not announcements regarding dividends cause abnormal returns or price changes around declaration date ${ }^{1}$.

Watts (1973) conducted the first empirical study of the information content of dividends. His study attempted to predict the relation between dividend changes and future profitability by using future profits and current dividends. Watts concluded that a relation exists, although weak, between unexpected changes in dividends and future profits. Following Watts' study, Genodes (1978), Penman (1984), and Aharony and Dotan (1994) conducted research yielding stronger results in the American context.

A positive correlation was found between dividend changes and future profitability according to analyses made by Nissim and Ziv (2001), conducted using 100,666 dividends during the period 1963-1998, and Zhau and Ruland (2006), conducted using 40,968 dividends during the period 1950-2003. Healy and Palepu (1988), conducted a study on distributing or withholding dividends for the period 1969-1989. The results suggested that managers attempt to give signals regarding their company's future earnings.

DeAngelo and Skinner (1996) conducted a study of 145 companies during the period 1980-1987, finding no relation between dividend changes and future profitability. Grullon, Michaely, Benartzi and Thaler (2005) obtained similar results. Bernartzi, Michaely and Thaler (1997) performed a detailed study of 7,186 dividend payouts of 1,025 companies for the period 1979-1991. The results suggest that dividend policy is correlated with past profits rather than future profitability.

Using a method different from that of their previous studies, Nissim and Ziv (2001) obtained results strongly supporting a connection between dividend changes and future profitability for two successive years. The new model of Nissim and Ziv (2001) has been criticized by Grullon, Michaely, Benartzi and Thaler (2005) based on 
the argument that future earnings are not linear.

Table 1. Summary of studies on the dividend signaling theory

\begin{tabular}{|c|c|c|c|c|c|}
\hline Authors & Country & \# of Company & \# of Dividend & Period & Results \\
\hline $\begin{array}{l}\text { Hussainey } \\
\text { (2009) }\end{array}$ & England & & 4.490 & 1996- 2002 & $\begin{array}{l}\text { Relation is found between dividend changes of } \\
\text { companies in financial loss and their future losses. }\end{array}$ \\
\hline $\begin{array}{l}\text { Flint, Tan and } \\
\text { Tian (2010) }\end{array}$ & Australia & 682 & 3.689 & $1989-2008$ & $\begin{array}{l}\text { Positive correlation is found between dividend ratio } \\
\text { and increase on future profitability. }\end{array}$ \\
\hline $\begin{array}{l}\text { Lukose and Rao } \\
\qquad \text { (2010) }\end{array}$ & India & & 9.523 & 1993-1998 & $\begin{array}{l}\text { A strong positive relation between dividend changes } \\
\text { and current year profit. No relation is detected } \\
\text { between dividend changes and future profits. }\end{array}$ \\
\hline $\begin{array}{l}\text { Vermuelen and } \\
\text { Smit (2011) }\end{array}$ & South Africa & & 12.669 & 1973- 2009 & $\begin{array}{l}\text { Positive correlation is found between dividend } \\
\text { changes and future profitability. }\end{array}$ \\
\hline $\begin{array}{c}\text { Agyei and } \\
\text { Yiadom (2011) }\end{array}$ & Ghana & 16 banks & & $1999-2003$ & $\begin{array}{l}\text { it is apparent that banks that pay dividend increase } \\
\text { their performance }\end{array}$ \\
\hline $\begin{array}{l}\text { Choi, Ju and } \\
\text { Park (2011) }\end{array}$ & Korea & & 3.805 & $1991-2007$ & $\begin{array}{l}\text { Positive correlation is found between dividend } \\
\text { changes and future profitability. }\end{array}$ \\
\hline $\begin{array}{l}\text { Lee, Isa and Lim } \\
\qquad \text { (2012) }\end{array}$ & Malaysia & & 2.396 & $1998-2007$ & $\begin{array}{l}\text { Poor correlation is found between dividend changes } \\
\text { and future profitability. }\end{array}$ \\
\hline Demontis (2013) & $\begin{array}{l}\text { Scandinavian } \\
\text { Countries }\end{array}$ & 812 & & $2005-2012$ & $\begin{array}{l}\text { No relation is found between dividend changes and } \\
\text { future profitability. }\end{array}$ \\
\hline $\begin{array}{l}\text { Al-Amarneh and } \\
\text { Yaseen (2014) }\end{array}$ & Jordan & 47 & & 2005-2011 & $\begin{array}{l}\text { Results are supportive for Dividend Signaling } \\
\text { Theory }\end{array}$ \\
\hline
\end{tabular}

In addition to dividend changes, there are many other factors that can affect the future profitability of the firms traded in stock markets (Riasi, 2015). For instance, future profitability might be affected by a firm's degree of competitiveness (Amiri Aghdaie et al., 2012; Porter, 1990), use of new marketing strategies (Riasi and Pourmiri, 2015, 2016), access to alternative sources of funding (Burns et al., 2008; Riasi, 2015), and managerial aptitude and education (Riasi and Asadzadeh, 2015).

\section{Data and Methodology}

\subsection{Data}

Our study utilizes the cash dividends per share and earning (net income after tax) of companies listed in Borsa Istanbul for the period 2004-2014 (11 years). Data regarding dividends distributed are included in the sample; however, companies making two or fewer cash dividend payouts within the 11-year period are excluded from the data set. The analysis includes 1,239 cash dividends per share $(D P S)$ and the earnings of 123 companies over 11 years. The DPS value is represented as 0 for years in which no payout is made. Table 2 categorizes 1,239 dividend payouts of 123 companies listed in Borsa Istanbul during the period 2004-2014 based on the increase or decrease of the DPS in a given year.

Table 2. Dividend payouts made by companies 2004-2014. In the table DPS stands for dividend per share

\begin{tabular}{ccccc}
\hline Year & \# of remained constant DPS & \# of Increased DPS & \# of Decreased DPS & \# of Total DPS \\
\hline 2004 & 21 & 57 & 14 & 92 \\
2005 & 24 & 46 & 35 & 105 \\
2006 & 20 & 60 & 27 & 107 \\
2007 & 16 & 46 & 47 & 109 \\
2008 & 24 & 23 & 67 & 114 \\
2009 & 33 & 47 & 37 & 117 \\
2010 & 27 & 58 & 34 & 119 \\
2011 & 20 & 63 & 36 & 119 \\
2012 & 30 & 53 & 36 & 119 \\
2013 & 22 & 56 & 41 & 119 \\
2014 & 27 & 52 & 40 & 119 \\
Total & $\mathbf{2 6 4}$ & $\mathbf{5 6 1}$ & $\mathbf{4 1 4}$ & $\mathbf{1 2 3 9}$ \\
\hline
\end{tabular}


Table 3 summarizes the statistics regarding cash dividends per share, net income after tax (earnings), changes in earnings, and earnings per share (EPS) of companies listed in Borsa Istanbul for the period 2004-2014.

Table 3. Descriptive statistics of variables

\begin{tabular}{cccccccc}
\hline & Mean & Median & Maximum & Minimum & Std.Dev. & Skewness & Kurtosis \\
\hline$\left(E P S_{1}-E P S_{0}\right) / F_{-1}$ & 0.03 & 0.01 & 22.33 & -21.46 & 1.78 & 2.05 & 94.02 \\
$\left(E P S_{2}-E P S_{1}\right) / F_{-1}$ & 0.00 & 0.01 & 12.44 & -27.72 & 1.32 & -8.52 & 200.56 \\
$\left(E_{0}-E_{-1}\right) / B_{-1}$ & 0.03 & 0.02 & 11.75 & -10.39 & 0.54 & 1.80 & 300.80 \\
$\left(E_{1}-E_{0}\right) / B_{-1}$ & -0.04 & 0.02 & 10.54 & -79.65 & 2.43 & -30.84 & 1,012 \\
$\left(E_{2}-E_{1}\right) / B_{-1}$ & 0.45 & 0.02 & 436.68 & -7.21 & 13.63 & 31.97 & 1,024 \\
$\left(E_{1}-E_{0}\right) / P_{-1}$ & 0.10 & 0.02 & 21.82 & -37.30 & 2.24 & -4.46 & 106.77 \\
$\left(E_{2}-E_{1}\right) / P_{-1}$ & 0.22 & 0.02 & 30.72 & -33.32 & 2.63 & 1.06 & 65.37 \\
$R \triangle D I V_{0}$ & -1.76 & 0.00 & 2,615 & $-2,580$ & 211.42 & 0.47 & 79.93 \\
$D P S$ & 65.00 & 11.54 & 3,020 & 0.00 & 224.83 & 8.10 & 81.25 \\
EPS & 1.51 & 0.45 & 111.37 & -25.32 & 6.20 & 12.18 & 190.79 \\
$R O E$ & 0.14 & 0.12 & 7.57 & -4.32 & 0.30 & 9.72 & 325.11 \\
\hline
\end{tabular}

Note. In the table EPS stands for earning per share, $E$ stands for earning (net profit after tax), DPS stands for dividend per share, ROE stands for return on equity and $R \Delta D I V_{0}$ refers to dividend changes between the previous and current year.

\subsection{Methodology}

In order to test the correlation between dividend changes and future profitability, this study makes use of the Equation (2), first proposed by Bernartzi, Michaely, and Thaler (1997); improved by Nissim and Ziv (2001); and used by Grullon, Michaely, Benartzi, and Thaler (2005), Lukose and Rao (2010), Choi, Ju, and Park (2011), and Lee, Isa and Lim (2012). Dividend changes are calculated for the all equations using Equation (1) ${ }^{3}$. Ordinary least square and panel regression are used to estimate equations.

$$
R \Delta D I V_{0}=\frac{D I V_{0}-D I V_{-1}}{D I V_{-1}}
$$

In the formula, $R \Delta D I V_{0}$ refers to dividend changes between the previous and current year, while $D I V_{0}$ refers to the dividend per share in the current year. Finally, $D I V_{-I}$ refers to the dividend per share in the previous year.

$$
\left(E_{t}-E_{t-1}\right) /_{P_{-1}}=\alpha_{0}+\alpha_{1} R \Delta D I V_{0}+\epsilon_{t}
$$

Equation (2) was developed by Bernartzi, Michaely and Thaler (1997) to test the correlation between dividend changes and future profitability. Nissim ve Ziv (2001) added the control variable, $R O E_{t-1}$, arguing that a control variable was missing for changes in earnings. Nissim and Ziv (2001) also asserted that changes in earnings stated in the equation should be determined by the book value rather than by the market value of equity. As a result, Equation (3) was developed.

$$
\left(E_{t}-E_{t-1}\right) /_{B_{-1}}=\alpha_{0}+\alpha_{1} R \Delta D I V_{0}+\alpha_{2} R O E_{t-1}+\epsilon_{t}
$$

Nissim and Ziv (2001) as well as DeAngelo and DeAngelo (1990) added a dummy variable to the equation of Bernartzi, Michaely and Thaler (1997) to produce Equation (4). This dummy variable represents dividend changes regardless of whether they increased or decreased (DPC represents an increase and DNC represents a decrease).

$$
\frac{\left(E_{t}-E_{t-1}\right)}{B_{-1}}=\alpha_{0}+\alpha_{1 p} D P C_{0} * R \Delta D I V_{0}+\alpha_{1 n} D N C_{0} * R \Delta D I V_{0}+\alpha_{2} R O E_{t-1}+\frac{\left(E_{0}-E_{-1}\right)}{B_{-1}}+\epsilon_{t}
$$

On the other hand, Lee, Isa and Lim (2012) used Equation (5) to test the correlation between dividend changes and future profitability. 


$$
\left(E P S_{t}-E P S_{t-1}\right) /_{F_{t-1}}=\alpha_{0}+\alpha_{1} R \Delta D I V_{0}+\alpha_{2} \operatorname{DIdum}_{0}+\epsilon_{t}
$$

In equations above, $t$ refers to next year and the year after next year, $E_{t}$ refers to earning (net income after tax) of current year, $E_{t-1}$ refers to earning of previous year, $P_{-1}$ refers to market value of equity of company shares as of previous year-end, $B_{-1}$ refers to book value of equity value as of previous year-end, $R O E_{t-1}$ refers to return on equity of previous year, $E P S_{t}$ refers to earning per share in current year, $E P S_{t-1}$ refers to earning per share in previous year, $F_{t-1}$ refers to price of company's shares as of previous year-end, and DIdum $_{0}$ refers to dummy variable indication whether the dividend is increased with regards to previous year or not.

This study investigates the correlation between current year dividend changes and changes in earnings over the next year $(t+1)$ and the year after next $(t+2)$. Therefore, Equations (2), (3), (4) and (5) are applied separately, and the results are provided in Section 4.

\section{Empirical Results}

Empirical studies based on time series data make an assumption of that the underlying time series are stationary. But, time series in finance usually are non-stationary or in other terms they have unit root. Some researchers argue that if the time series variables are non-stationary, using data in levels may result in non constant mean over time and residuals which are highly autocorrelated with low Durbin-Watson statistics (Kutty, 2010).

In this study, all variables tested whether they have unit root. For this purpose Levin, Lin and Chu (2002), Im, Pesaran and Shin (2003), Augmented Dickey-Fuller (1979) and the Phillips and Perron (1998) unit root tests are applied at the level for the individual intercept equation. According to test results none of variables have unit root. The selected results given in the Table 4.

Table 4. Results of unit root tests

\begin{tabular}{lcccccccc}
\hline & \multicolumn{3}{c}{$D P S$} & \multicolumn{2}{c}{$E P S$} & \multicolumn{2}{c}{$R O E$} & \multicolumn{2}{c}{$R \Delta D I V_{0}$} \\
\hline Method & Stat. & Prob. & Stat. & Prob. & Stat. & Prob. & Stat. & Prob. \\
Levin, Lin \& Chu t* & -17.2 & 0.00 & -27.7 & 0.00 & -10.5 & 0.00 & -24.6 & 0.00 \\
Im, Pesaran and Shin W-stat & -3.61 & 0.00 & -7.3 & 0.00 & -6.8 & 0.00 & -12.7 & 0.00 \\
ADF - Fisher Chi-square & 362 & 0.00 & 403 & 0.00 & 425 & 0.00 & 595 & 0.00 \\
PP - Fisher Chi-square & 466 & 0.00 & 682 & 0.00 & 766 & 0.00 & 1296 & 0.00 \\
\hline
\end{tabular}

Note. All statistics are significant at $1 \%$.

Equations (2), (3), (4) and (5) are applied individually to test whether or not current year dividend changes correlate with earnings in the next year and the year after next. Tables 5 to 9 present the results.

Table 5 summarizes the results of Equation (2), developed by Bernartzi, Michaely and Thaler (1997).

Table 5. Results of equation (2)

\begin{tabular}{|c|c|c|c|c|c|}
\hline \multicolumn{6}{|c|}{$\left(E_{t}-E_{t-1}\right) / P_{-1}=\alpha_{0}+\alpha_{1} R \Delta D I V_{0}+\epsilon_{t}$} \\
\hline & & \multicolumn{2}{|c|}{ Ordinary Least Square Regression } & \multicolumn{2}{|c|}{ Two-way Fixed Effect Panel Regression } \\
\hline \multirow{5}{*}{ Next Year } & Variable & Coefficient & Probability & Coefficient & Probability \\
\hline & C & 0.05546 & 0.37 & 0.05552 & 0.37 \\
\hline & $R \Delta D I V_{0}$ & -0.00042 & 0.15 & -0.00046 & 0.12 \\
\hline & $F$-statistics & 2.07 & 0.15 & 0.77469 & 0.97 \\
\hline & $R^{2}$ & \multicolumn{2}{|c|}{0,002} & \multicolumn{2}{|c|}{0.091} \\
\hline \multirow{5}{*}{ In Two Years } & Variable & Coefficient & Probability & Coefficient & Probability \\
\hline & $C$ & $0.16978^{* *}$ & 0.03 & $0.17009^{* *}$ & 0.03 \\
\hline & $R \Delta D I V_{0}$ & 0.00057 & 0.10 & 0.00047 & 0.20 \\
\hline & $F$-statistics & $2.68^{*}$ & 0.10 & 0.62345 & 0.99 \\
\hline & $R^{2}$ & \multicolumn{2}{|c|}{0.003} & \multicolumn{2}{|c|}{0.084} \\
\hline
\end{tabular}

Note. $*$ shows $10 \%, * *$ shows $5 \%$ and $* * *$ shows $1 \%$ significance level. As the data is unbalanced, the two-way random effects model could not be applied due to missing data. In the one-way random-effects model, model Hausman test favored the fixed effects model.

Given the probability of the coefficient of $R \Delta D I V_{0}$ shown in Table 5, no significant relation is found between 
dividend changes and changes in earnings in the next year or the year after next.

Nissim and Ziv (2001) argued that changes in earnings in Equation (2) should be adjusted based on book value rather than market value of equity. Table 6 gives the results of Equation (2) when it is recalculated based on this assumption.

Table 6. Results of equation (2) with readjusted values for future earning changes

\begin{tabular}{|c|c|c|c|c|c|}
\hline \multicolumn{6}{|c|}{$\left(E_{t}-E_{t-1}\right) / B_{-1}=\alpha_{0}+\alpha_{1} R \Delta D I V_{0}+\epsilon_{t}$} \\
\hline & & \multicolumn{2}{|c|}{ Ordinary Least Square Regression } & \multicolumn{2}{|c|}{ Two-way Fixed Effect Panel Regression } \\
\hline \multirow{5}{*}{ Next Year } & Variable & Coefficient & Probability & Coefficient & Probability \\
\hline & $C$ & -0.03993 & 0.58 & -0.04004 & 0.57 \\
\hline & $R \Delta D I V_{0}$ & -0.00005 & 0.88 & -0.00003 & 0.93 \\
\hline & $F$-statistics & 0.05 & 0.88 & $1.26^{* *}$ & 0.03 \\
\hline & $R^{2}$ & \multicolumn{2}{|c|}{0.00002} & \multicolumn{2}{|c|}{0.14} \\
\hline \multirow{5}{*}{ In Two Years } & Variable & Coefficient & Probability & Coefficient & Probability \\
\hline & C & 0.45002 & 0.29 & 0.451166 & 0.28 \\
\hline & $R \Delta D I V_{0}$ & -0.00003 & 0.99 & -0.000449 & 0.82 \\
\hline & F-statistics & 0.0003 & 0.99 & $1.22^{*}$ & 0.05 \\
\hline & $R^{2}$ & \multicolumn{2}{|c|}{0.000} & \multicolumn{2}{|c|}{0.15} \\
\hline
\end{tabular}

Note. ${ }^{*}$ shows $10 \%,{ }^{* *}$ shows $5 \%$ and ${ }^{* * *}$ shows $1 \%$ significance level. As the data is unbalanced, the two-way random effects model could not be applied due to missing data. In the one-way random-effects model, model Hausman test favored the fixed effects model.

Given the probability of the coefficient of $R \Delta D I V_{0}$ shown in Table 6, no statistically significant relation is found between dividend changes and changes in earnings in the next year or the year after next. Table 7 displays the results of Equations (3) and (4) suggested by Nissim and Ziv (2001).

Table 7. Results of equation (3)

\begin{tabular}{|c|c|c|c|c|c|}
\hline \multicolumn{6}{|c|}{$\left(E_{t}-E_{t-1}\right) / B_{-1}=\alpha_{0}+\alpha_{1} R \Delta D I V_{0}+\alpha_{2} R O E_{t-1}+\epsilon_{t}$} \\
\hline & & \multicolumn{2}{|c|}{ Ordinary Least Square Regression } & \multicolumn{2}{|c|}{ Two-way Fixed Effect Panel Regression } \\
\hline \multirow{6}{*}{ Next Year } & Variable & Coefficient & Probability & Coefficient & Probability \\
\hline & $C$ & $0.21051^{* *}$ & 0.01 & $0.26671^{* * *}$ & 0.00 \\
\hline & $R \Delta D I V_{0}$ & -0.00013 & 0.69 & -0.00003 & 0.92 \\
\hline & $R O E_{t-1}$ & $-1.91264^{* * *}$ & 0.00 & $-2.34304^{* * *}$ & 0.00 \\
\hline & F-statistics & $15.81^{* * *}$ & 0.00 & $1.54^{* * *}$ & 0.00 \\
\hline & $R^{2}$ & \multicolumn{2}{|c|}{0.03} & \multicolumn{2}{|c|}{0.17} \\
\hline \multirow{6}{*}{$\begin{array}{l}\text { In Two } \\
\text { Years }\end{array}$} & Variable & Coefficient & Probability & Coefficient & Probability \\
\hline & $C$ & -0.60534 & 0.22 & -0.69434 & 0.18 \\
\hline & $R \Delta D I V_{0}$ & 0.00040 & 0.83 & -0.00018 & 0.93 \\
\hline & $R O E_{t-1}$ & $8.04007^{* * *}$ & 0.00 & $8.72936^{* * *}$ & 0.00 \\
\hline & $F$-statistics & $8.43^{* * *}$ & 0.00 & $1.34^{* *}$ & 0.01 \\
\hline & $R^{2}$ & \multicolumn{2}{|c|}{0.02} & \multicolumn{2}{|c|}{0.17} \\
\hline
\end{tabular}

Note. $*$ shows $10 \%$, ** shows $5 \%$ and $* * *$ shows $1 \%$ significance level. As the data is unbalanced, the two-way random effects model could not be applied due to missing data. In the one-way random-effects model, model Hausman test favored the fixed effects model.

Given the probability value of the coefficient of $R \Delta D I V_{0}$ in the results shown in Table 7 , no statistically significant relation is found between dividend changes and changes in earnings in the next year and the year after next. The coefficient of $R O E_{t-1}$ in both regressions shows that the previous year's profitability has significant impact on future profitability and changes in future earnings. 
Table 8. Results of equation (4)

\begin{tabular}{|c|c|c|c|c|c|}
\hline \multicolumn{6}{|c|}{$\left(E_{t}-E_{t-1}\right) / B_{-1}=\alpha_{0}+\alpha_{1 p} D P C_{0} * R \Delta D I V_{0}+\alpha_{1 n} D N C_{0} * R \Delta D I V_{0}+\alpha_{2} R O E_{t-1}+\left(E_{0}-E_{-1}\right) / B_{-1}+\epsilon_{t}$} \\
\hline & & \multicolumn{2}{|c|}{ Ordinary Least Square Regression } & \multicolumn{2}{|c|}{ Two-way Fixed Effect Panel Regression } \\
\hline \multirow{8}{*}{ Next Year } & Variable & Coefficient & Probability & Coefficient & Probability \\
\hline & $C$ & $0.16036^{*}$ & 0.06 & $0.18417^{* *}$ & 0.04 \\
\hline & $D P C_{0} * R \Delta D I V_{0}$ & -0.00005 & 0.91 & -0.00017 & 0.73 \\
\hline & $D N C_{0} * R \Delta D I V_{0}$ & -0.00038 & 0.46 & -0.00004 & 0.94 \\
\hline & $R O E_{t-1}$ & $-1.71212^{* * *}$ & 0.00 & $-1.85777^{* * *}$ & 0.00 \\
\hline & $\left(E_{0}-E_{-1}\right) / B_{-1}$ & $0.66233^{* * *}$ & 0.00 & $0.95210^{* * * *}$ & 0.00 \\
\hline & $F$-statistics & $14.69^{* * *}$ & 0.00 & $1.97^{* * *}$ & 0.00 \\
\hline & $R^{2}$ & \multicolumn{2}{|c|}{0.05} & \multicolumn{2}{|c|}{0.21} \\
\hline \multirow{8}{*}{$\begin{array}{l}\text { In Two } \\
\text { Years }\end{array}$} & Variable & Coefficient & Probability & Coefficient & Probability \\
\hline & C & 0.01256 & 0.99 & 0.27344 & 0.57 \\
\hline & $D P C_{0} * R \Delta D I V_{0}$ & 0.00034 & 0.89 & 0.00094 & 0.72 \\
\hline & $D P C_{0} * R \Delta D I V_{0}$ & 0.00232 & 0.41 & 0.00073 & 0.82 \\
\hline & $R O E_{t-1}$ & $5.44172^{* * *}$ & 0.00 & $3.49991^{*}$ & 0.10 \\
\hline & $\left(E_{0}-E_{-1}\right) / B_{-1}$ & $-8.37155^{* * *}$ & 0.00 & $-10.6977^{* * *}$ & 0.00 \\
\hline & $F$-statistics & $40.91^{* * *}$ & 0.00 & $3.36^{* * *}$ & 0.00 \\
\hline & $R^{2}$ & \multicolumn{2}{|c|}{0.14} & \multicolumn{2}{|c|}{0.34} \\
\hline
\end{tabular}

Note. $*$ shows $10 \%$, ** shows $5 \%$ and $* * *$ shows $1 \%$ significance level. As the data is unbalanced, the two-way random effects model could not be applied due to missing data. In the one-way random-effects model, model Hausman test favored the fixed effects model.

Given the probability values of the coefficients of $D P C_{0} * R \Delta D I V_{0}$ and $D N C_{0} * R \Delta D I V_{0}$, no statistically significant relation is found between dividend changes and changes in earnings in the next year or the year after next. The coefficient of $R O E_{t-1}$ in both regressions shows that the previous year's profitability has significant impact on future profitability and changes in future earnings.

Table 9 gives the results of Equation (5) as proposed by Lee, Isa, and Lim (2012).

Table 9. Results of equation (5)

\begin{tabular}{|c|c|c|c|c|c|}
\hline \multicolumn{6}{|c|}{$\left(E P S_{t}-E P S_{t-1}\right) / F_{t-1}=\alpha_{0}+\alpha_{1} R \Delta D I V_{0}+\alpha_{2}$ DIdum $_{0}+\epsilon_{t}$} \\
\hline & & \multicolumn{2}{|c|}{ Ordinary Least Square Regression } & \multicolumn{2}{|c|}{ Two-way Fixed Effect Panel Regression } \\
\hline \multirow{6}{*}{ Next Year } & Variable & Coefficient & Probability & Coefficient & Probability \\
\hline & C & -0.097141 & 0.14 & -0.080769 & 0.24 \\
\hline & $R \Delta D I V_{0}$ & $0.000957^{* * *}$ & 0.00 & $0.000982^{* * *}$ & 0.00 \\
\hline & DIdum $_{0}$ & $0.217997^{* *}$ & 0.03 & $0.181824^{*}$ & 0.10 \\
\hline & F-statistics & $13.59^{* * *}$ & 0.00 & 1.14 & 0.14 \\
\hline & $\mathrm{R}^{2}$ & \multicolumn{2}{|c|}{0.02} & \multicolumn{2}{|c|}{0.13} \\
\hline \multirow{6}{*}{$\begin{array}{c}\text { In Two } \\
\text { Years }\end{array}$} & Variable & Coefficient & Probability & Coefficient & Probability \\
\hline & C & 0.035369 & 0.39 & 0.032821 & 0.47 \\
\hline & $R \Delta D I V_{0}$ & -0.000036 & 0.80 & -0.000035 & 0.82 \\
\hline & DIdum $_{0}$ & -0.042206 & 0.50 & -0.036574 & 0.61 \\
\hline & $F$-statistics & 0.32 & 0.72 & 0.23 & 1.00 \\
\hline & $R^{2}$ & \multicolumn{2}{|c|}{0.00} & \multicolumn{2}{|c|}{0.03} \\
\hline
\end{tabular}

Note. $*$ shows $10 \%$, ** shows $5 \%$ and $* * *$ shows $1 \%$ significance level. As the data is unbalanced, the two-way random effects model could not be applied due to missing data. In the one-way random-effects model, model Hausman test favored the fixed effects model.

Evaluating the results of Equation (5), a correlation is found with $1 \%$ significance between current dividend changes and changes in earnings in the next year when both ordinary regression and panel regression are applied. However, this relation is not found in the year after next.

To summarize, data concerning 1,239 dividends from 123 companies listed in Borsa Istanbul during the period 2004-2014 are analyzed using five different models proposed by Bernartzi, Michaely, and Thaler (1997); Nissim and Ziv (2001); Grullon, Michaely, Benartzi, and Thaler (2005); Choi, Ju, and Park (2011); Lee, Isa, and Lim (2012), respectively. It can be concluded that dividend changes and future profitability do not correlate. On the 
other hand, future profitability or changes in future earnings strongly correlate with profitability in the previous year. Therefore, the dividend signaling theory is not supported in the Turkish context.

The results obtained do not adhere to expectations, since previous studies on Turkish Stock Market reached conclusions regarding the information content of dividends by analyzing whether dividend announcements cause abnormal returns or changes in price. One of the possible explanation of such contradiction could be that the information content of dividend changes with regard to future profitability is viewed as highly improbable in a structure emphasizing capital gains due to lower tax rate than dividend yield in Turkey (Kadığlu; 2008, 2011). Hence, it can be concluded that shareholders in Turkey aim to make capital gains from price movements rather than receive income from dividend yields.

\section{Conclusions}

The information content of dividends, first proposed by Lintner (1956), Miller and Modigliani (1961) and later formulized by Bhattacharya (1979), John and Williams (1985), Miller and Rock (1985) as the signaling theory, has been the subject of debate for over 50 years. Results of studies regarding this theory are inconclusive; studies have emerged both supporting and contradicting the dividend signaling theory, which argues that a correlation exists between dividend changes and future profitability.

This study is the first to test the relationship between dividend changes and future profitability in Turkey. The data set includes 1,239 dividend payouts made by 123 companies listed in Borsa Istanbul during period 2004-2014. The data are analyzed using five different models introduced by Bernartzi, Michaely, and Thaler (1997); improved by Nissim and Ziv (2001) and later used by Grullon, Michaely, Benartzi, and Thaler (2005); Lukose and Rao (2010); Choi, Ju, and Park (2011); and Lee, Isa, and Lim (2012).

No statistically significant relation is found between dividends or dividend changes and changes in earnings over the following two years. Therefore, it can be concluded that dividends or dividend changes do not convey information regarding future profitability. In other words, the dividend signaling theory is not supported. On the other hand, the future profitability strongly correlate with profitability in the previous year.

The results obtained do not adhere to expectations, since previous studies on Turkish Stock Market reached conclusions regarding the information content of dividends by analyzing whether dividend announcements cause abnormal returns or changes in price. This is most likely due to the fact that capital gains are taxed at a lower rate than dividend yields in Turkey. Therefore, structural changes including alterations in taxation policy may contribute to the development of capital markets in Turkey by giving dividend yields equal significance with capital gains.

It may also be beneficial to test the relation between dividends or dividend changes and future profitability or changes in earnings using nonlinear models.

\section{References}

Aharony, J., \& Dotan, A. (1994). Regular dividend announcements and future unexpected earnings: An empirical analysis. Financial Review, 29(1), 125-151. http://dx.doi.org/10.1111/j.1540-6288.1994.tb00816.x

Aharony, J., \& Swary, I. (1980). Quarterly Dividend and Earnings Announcements and Stockholders' Returns: An Empirical Analysis. Journal of Finance, 35, 1-12. http://dx.doi.org/10.2307/2327176

Ali, M. B., \& Chowdhury, T. A. (2010). Effect of Dividend on Stock Price in Emerging Stock Market: A Study on the Listed Private Commercial Banks in DSE. International Journal of Economics and Finance, 2(4), 52-64. http://dx.doi.org/10.5539/ijef.v2n4p52

Amiri Aghdaie, S. F., Seidi, M., \& Riasi, A. (2012). Identifying the Barriers to Iran's Saffron Export by Using Porter's Diamond Model. International Journal of Marketing Studies, 4(5), 129-138. http://dx.doi.org/10.5539/ijms.v4n5p129

Asquith, P., \& Mullins, D. W. (1983). The Impact of Initiating Dividend Payments on Shareholders' Wealth. Journal of Business, 56, 77-96. http://dx.doi.org/10.1086/296187

Aydogan, K., \& Muradoglu, G. (1998). Do markets learn from experience? Price reaction to stock dividends in the Turkish market. Applied Financial Economics, 8, 41-49. http://dx.doi.org/10.1080/096031098333230

Batchelor, R., \& Orgakcioglu, I. (2003). Event-related GARCH: the impact of stock dividends in Turkey. Applied Financial Economics, 13, 295-307. http://dx.doi.org/10.1080/09603100210138547

Benartzi, S., Michaely, R., \& Thaler, R. H. (1997). Do changes in dividends signal the future or the past? Journal of Finance, 52(3), 1007-1034. http://dx.doi.org/10.2307/2329514 
Bhattacharya, S. (1979). Imperfect information, dividend policy, and "the bird in the hand" fallacy. Bell Journal of Economics, 10 (Spring), 259-270.

Burns, D. C., Sale, J. T., \& Stephan, J. A. (2008). A better way to gauge profitability. Journal of Accountancy, 206(2), 38.

Chen, G., Firth, M., \& Gao, N. (2002). The Information Content of Concurrently Announced Earnings, Cash Dividends, and Stock Dividends: An Investigation of the Chinese Stock Market. Journal of International Financial Management \& Accounting, 13(2), 101-124. http://dx.doi.org/10.1111/1467-646X.00080

Choi, Y. M., Ju, H. K., \& Park, Y. K. (2011). Do dividend changes predict the future profitability of firms? Accounting and Finance, 51(4), 869-891. http://dx.doi.org/10.1111/j.1467-629X.2010.00379.x

DeAngelo, H., DeAngelo, L., \& Skinner, D. (1996). Reversal of fortune: Dividend policy and the disappearance of sustained earnings growth. Journal of Financial Economics, 40(2), 341-371.

Demontis, M. D. B. (2013). A study of the Dividend Signaling theory on the Scandinavian market. MSc Dissertation Thesis, Business and Social Sciences, Aarhus University

Dickey, D. A., \& Fuller, W. A. (1979). Autoregressive Time Series with a Unit Root. Journal of the American Statistical Association, 74, 427-431.

Gonedes, N. J. (1978). Corporate signaling, external accounting, and capital market equilibrium: Evidence on dividends, income, and extraordinary items. Journal of Accounting Research, 16(Spring), 26-79. http://dx.doi.org/10.2307/2490411

Grullon, G., Michaely, R., Bernartzi, S., \& Thaler, H. R. (2005). Dividend Changes Do Not Signal Changes in Future Profitability. Journal of Business, 78, 1659-1682. http://dx.doi.org/10.1086/431438

Gullajov, N. (2014). The Announcement Effect of Cash Dividends on Share Prices: Evidence from Borsa Istanbul. Birmingham University, Business School, MSc Dissertation Thesis.

Günalp, B., Kadığlu, E., \& Kılıc, S. (2010). Information content of the cash dividend: An empirical study on Istanbul stock exchange. Hacettepe University Journal of Economics and Administrative Sciences, 28(2), 47-69.

Healy, P., \& Palepu, K. (1988). Earnings information conveyed by dividend initiations and omissions. Journal of Financial Economics, 21, 149-175. http://dx.doi.org/10.1016/0304-405X(88)90059-1

Hussainey, K. (2009). Do dividends signal information about future earnings? Applied Economics Letters, 16, 1285-1288. http://dx.doi.org/10.1080/17446540802403635

Im, K. S., Pesaran, M. H., \& Shin, Y. (2003). Testing for unit roots in heterogeneous panels. Journal of Econometrics, 115(1), 53-74. http://dx.doi.org/10.1016/S0304-4076(03)00092-7

John, K., \& Williams, J. (1985). Dividends, dilution, and taxes: A signaling equilibrium. Journal of Finance, 40(September), 1053-1070. http://dx.doi.org/10.2307/2328394

Kadığlu, E. (2008). The announcement effect of cash dividend: Evidence from Turkish capital market. University of Leeds, Business School, MSc Dissertation Thesis.

Kadıoğlu, E., Telçeken, N., \& Öcal. N. (2015). Market Reaction to Dividend Announcement: Evidence from Turkish Stock Market. International Business Research, 8(9), 83-94 http://dx.doi.org/10.5539/ibr.v8n9p83

Kutty, G. (2010). The Relationship Between Exchange Rates and Stock Prices: The Case of Mexico. North American Journal of Finance and Banking Research, 4(4), 1-13.

Laub, P. M. (1976). On the Informational Content of Dividends. Journal of Business, 49, 73-80. http://dx.doi.org/10.1086/295811

Lee, S. P., Isa, M., \& Lim, W. L. (2012). Dividend Changes and Future Profitability: Evidence from Malaysia. Asian Academy of Management Journal of Accounting and Finance, 8(2), 93-110.

Levin, A., Lin, C. F., \& Chu, J. (2002). Unit root tests in panel data: Asymptotic and finite-sample properties. Journal of Econometrics, 108(1), 1-24. http://dx.doi.org/10.1016/S0304-4076(01)00098-7

Lintner, J. (1956). Distribution of incomes of Corporations Among dividends, Retained Earnings and Taxes. American Economic Review, 5, 97-113.

Lukose, J., \& Rao, S. N. (2010). Dividend changes and profitability: An empirical study of Indian manufacturing firms. The IUP Journal of Applied Finance, 16(1), 5-26. 
Miller, M. H., \& Modigliani F. (1961). Dividend policy, growth, and the valuation of shares. Journal of Business, 34, 411-433. http://dx.doi.org/10.1086/294442

Miller, M. H., \& Rock, K. (1985). Dividend policy under asymmetric information. Journal of Finance, 40(September), 1031-1051. http://dx.doi.org/10.2307/2328393

Muradoğlu, G., \& Aydoğan, K. (2003). Trends in market reactions: Stock dividends and rights offerings at Istanbul stock exchange. The European Journal of Finance, 9, 41-60. http://dx.doi.org/10.1080/13518470110047611

Nissim, D., \& Ziv, A. (2001). Dividend Changes and Future Profitability. Journal of Finance, 56, 2111-2133. http://dx.doi.org/10.1111/0022-1082.00400

Penman, S. H. (1983). The predictive content of earnings forecasts and dividends. Journal of Finance, 38(September), 1181-1199. http://dx.doi.org/10.2307/2328019

Pettit, R. (1972). Dividend Announcements, Security Performance, and Capital Market Efficiency. Journal of Finance, 5, 993-1007. http://dx.doi.org/10.2307/2978844

Phillips, P. C. B., \& Perron, P. (1988). Testing for a Unit Root in Time Series Regression. Biometrika, 75(2), 335-346. http://dx.doi.org/10.1093/biomet/75.2.335

Porter, M. E. (1990). The Competitive Advantage of Nations. New York, NY: The Free Press.

Riasi, A. (2015). Competitive Advantages of Shadow Banking Industry: An Analysis Using Porter Diamond Model. Business Management and Strategy, 6(2), 15-27. http://dx.doi.org/10.5296/bms.v6i2.8334

Riasi, A., \& Asadzadeh, N. (2015). The relationship between principals' reward power and their conflict management styles based on Thomas-Kilmann conflict mode instrument. Management Science Letters, 5(6), 611-618. http://dx.doi.org/10.5267/j.msl.2015.4.004

Riasi, A., \& Pourmiri, S. (2015). Effects of online marketing on Iranian ecotourism industry: Economic, sociological, and cultural aspects. Management Science Letters, 5(10), 915-926. http://dx.doi.org/10.5267/j.msl.2015.8.005

Riasi, A., \& Pourmiri, S. (2016). Examples of Unsustainable Tourism in Middle East. Environmental Management and Sustainable Development, 5(1), 69-85. http://dx.doi.org/10.5296/emsd.v5i1.8705

Travlos, N., Trigeorgis, L., \& Vafeas, N. (2001). Shareholder Wealth Effects of Dividend Policy Changes in an Emerging Stock Market: The Case of Cyprus. Multinational Finance Journal, 5(2), 87-112.

Watts, R. (1973). The information content of dividends. Journal of Business, 46, 191-211.

Woolridge, J. R. (1982). The Information Content of Dividend Changes. Journal of Financial Research, 5, 237-247. http://dx.doi.org/10.1086/295525

Yilmaz, A. A., \& Selcuk, E. A. (2010). Information Content of Dividends: Evidence from Istanbul Stock Exchange. International Business Research, 3(3), 126-132.

Zhau, P., \& Ruland, P. (2006). Dividend Payout and Future Earnings Growth. Financial Analysts Journal, 62, 58-69. http://dx.doi.org/10.2469/faj.v62.n3.4157

\section{Notes}

Note 1. See the following studies for more information: Pettit (1972); Laubn(1976); Aharony and Swary (1980); Woolridge (1982); Asquith and Mullins (1983),Travlos et al. (2001); Chen, Firth, and Gao (2002); Ali and Chowdhury (2010).

Note 2. For the purposes of this study, earnings refers to net income after tax.

Note 3. In our sample, dividend payout is the dividend per share, therefore to find RADIV last year's DPS is simply subtracted from the current year's DPS.

\section{Copyrights}

Copyright for this article is retained by the author(s), with first publication rights granted to the journal.

This is an open-access article distributed under the terms and conditions of the Creative Commons Attribution license (http://creativecommons.org/licenses/by/3.0/). 